\title{
Transcriptome Analysis of Paralichthys olivaceus Erythrocytes Reveals Profound Immune Responses Induced by Edwardsiella tarda Infection
}

\author{
Bin Sun ${ }^{1,2,3}{ }^{\mathbb{D}}$, Xuepeng $\mathrm{Li}^{1}$, Xianhui Ning ${ }^{1}$ and $\operatorname{Li}$ Sun ${ }^{1,2, *}$ \\ 1 CAS Key Laboratory of Experimental Marine Biology, CAS Center for Ocean Mega-Science, \\ Institute of Oceanology, Chinese Academy of Sciences, 7 Nanhai Road, Qingdao 266071, China; \\ sunbin17@mails.ucas.ac.cn (B.S.); lixuepeng14@mails.ucas.ac.cn (X.L.); xhningouc@163.com (X.N.) \\ 2 Laboratory for Marine Biology and Biotechnology, Qingdao National Laboratory for Marine Science and \\ Technology, 1 Wenhai Road, Qingdao 266237, China \\ 3 University of Chinese Academy of Sciences, 19 Yuquan Road, Beijing 100049, China \\ * Correspondence: lsun@qdio.ac.cn; Tel.: +86-532-82898829
}

Received: 13 March 2020; Accepted: 3 April 2020; Published: 28 April 2020

\begin{abstract}
Unlike mammalian red blood cells (RBCs), fish RBCs are nucleated and thus capable of gene expression. Japanese flounder (Paralichthys olivaceus) is a species of marine fish with important economic values. Flounder are susceptible to Edwardsiella tarda, a severe bacterial pathogen that is able to infect and survive in flounder phagocytes. However, the infectivity of and the immune response induced by E. tarda in flounder RBCs are unclear. In the present research, we found that E. tarda was able to invade and replicate inside flounder RBCs in both in vitro and in vivo infections. To investigate the immune response induced by E. tarda in RBCs, transcriptome analysis of the spleen RBCs of flounder challenged with E. tarda was performed. Six sequencing libraries were constructed, and an average of 43 million clean reads per library were obtained, with $85 \%$ of the reads being successfully mapped to the genome of flounder. A total of 1720 differentially expressed genes (DEGs) were identified in E. tarda-infected fish. The DEGs were significantly enriched in diverse Gene Ontology (GO) terms and Kyoto Encyclopedia of Genes and Genomes (KEGG) pathways, especially those associated with immunity, disease, and infection. Ninety-one key DEGs involved in 12 immune-related pathways were found to form extensive interaction networks. Twenty-one genes that constituted the hub of the networks were further identified, which were highly regulated by E. tarda and involved in a number of immune processes, notably pathogen recognition and signal transduction, antigen processing and presentation, inflammation, and splicing. These results provide new insights into the immune role of flounder RBCs during bacterial infection.
\end{abstract}

Keywords: Paralichthys olivaceus; red blood cells; Edwardsiella tarda; transcriptome; immune response

\section{Introduction}

Red blood cells (RBCs) are the most abundant cell type in the blood. While the mammalian mature RBCs lack nuclei, the RBCs of non-mammals contain nuclei and cytoplasmic organelles, which suggests the ability to synthesize proteins in response to stimuli [1-4]. Recently, nucleated RBCs have been reported to be involved in various immune responses when stimulated with pathogens such as Escherichia coli [5], Candida albicans [6,7], infectious salmon anemia virus (ISAV) [8], piscine orthoreovirus (PRV) [2], non-replicating viruses like viral hemorrhagic septicemia virus (VHSV) [9], and infectious pancreatic necrosis virus (IPNV) [1,10]. The nucleated RBCs express pattern recognition receptors (PRRs) that recognize pathogen-associated molecular patterns (PAMPs) on microorganisms [11,12]. In fish, rainbow trout and Atlantic salmon RBCs express Toll-like receptor (TLR) 3 and TLR9 that recognize 
CpG motifs [7,13-15]. Atlantic salmon RBCs also express RIG-I that interacts with intracellular viral dsRNA [14]. NOD2, NLRX1, NLRC3, and NLRC5 receptors of NOD-like receptors (NLRs) family were detected in rainbow trout RBCs stimulated with VHSV [11]. The activation of the PRRs of nucleated RBCs has been reported to trigger signal transductions and induce the transcription of diverse genes related to innate immunity, such as interferon, interleukin, chemokines, and antimicrobial peptide [12]. In addition, nucleated RBCs also display an antigen-presenting cell (APC)-like behavior, and fish RBCs have been reported to express MHC-I and MHC-II [16-20]. The MHC-I and MHC-II exposed on the surface of RBCs can be recognized by T cells and activate the adaptive immunity [12].

Edwardsiella tarda is a gram-negative bacteria that is known to infect a wide range of hosts, including birds, reptiles, mammals, and fish [21,22]. It is a severe pathogen to many farmed fish species, including Japanese flounder (Paralichthys olivaceus), and has caused huge economic losses in aquaculture [23]. Studies have shown that $E$. tarda exhibits a strong capacity to evade host immune responses and is able to replicate in host macrophages and resist the killing effect of serum complements [24,25]. A recent study revealed that $E$. tarda markedly suppressed the induction of a large amount of immune genes, notably RIG-I-like receptors, cytokines, and interferon-related genes, during its infection of mammalian macrophages [26]. In a previous report, we demonstrated that Japanese flounder RBCs were capable of ingesting both live and inactivated E. tarda, the former via clathrin-mediated endocytosis [27]. However, the immune response induced by E. tarda in flounder RBCs has not been investigated.

In this study, we examined the capacity of $E$. tarda to invade and replicate in flounder RBCs, and analyzed the transcriptome of flounder spleen erythrocytes induced by E. tarda challenge. We identified a large amount of differentially expressed genes (DEGs) and analyzed their functional enrichment in Gene Ontology (GO) and Kyoto Encyclopedia of Genes and Genomes (KEGG) pathways. Further, we constructed protein-protein interaction networks to reveal the key immune-related DEGs involved in E. tarda infection. Our results provided a valuable molecular basis for further study of the mechanism of flounder erythrocytes against bacterial infection.

\section{Results}

\subsection{In Vitro Infection of E. tarda in RBCS}

Our previous study indicated that E. tarda could invade into flounder RBCs [27]. To examine whether E. tarda was able to replicate inside RBCs, the bacteria attached to the surface of RBCs were killed with antibiotics, and the cells were incubated further for $2 \mathrm{~h}$ and $4 \mathrm{~h}$. Plate count showed that the intracellular bacterial number increased with the incubation time (Figure 1), indicating an ability of E. tarda to replicate inside RBCs.

\subsection{In Vivo Infection of E. tarda in Flounder Blood and Spleen Erythrocytes}

For in vivo infection, flounder were infected with E. tarda for $12 \mathrm{~h}$ or $24 \mathrm{~h}$. Erythrocytes were collected from the blood and spleen of the fish and purified to high purity ( $\geq 98 \%$ ) (Figure S1). Both cell surface-attached and intracellular E. tarda were detected in the erythrocytes of the infected fish (Figure 2). No E. tarda were detected from the erythrocytes of the uninfected control fish. In E. tarda-infected fish, both cell surface-attached and intracellular bacterial numbers increased significantly from $12 \mathrm{~h}$ to $24 \mathrm{~h}$ (Figure 2). Furthermore, at both time points, the numbers of intracellular E. tarda in spleen erythrocytes were much higher (2.5 and 3.7 times, respectively) than that in blood erythrocytes, suggesting a more robust bacteria-host cell interaction in spleen RBCs. For this reason, as well as the fact that spleen is one of the major immune organs and an important origin of erythropoiesis in teleost, the spleen erythrocytes from infected and uninfected fish were used for subsequent transcriptome analysis described below. 


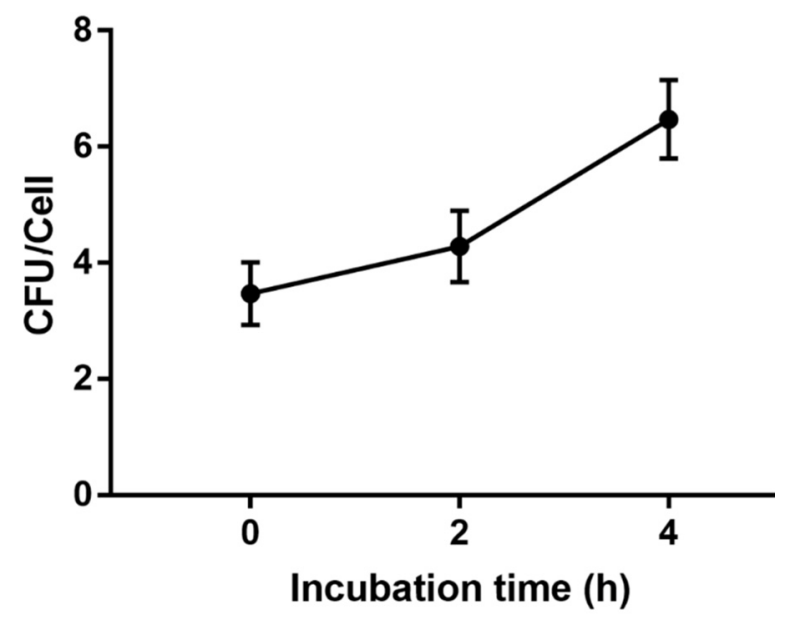

Figure 1. Intracellular replication of Edwardsiella tarda in flounder red blood cells (RBCs). RBCs were infected with $E$. tarda for $3 \mathrm{~h}$, and the extracellular bacteria were killed with antibiotic. The cells were then incubated for $0 \mathrm{~h}, 2 \mathrm{~h}$, or $4 \mathrm{~h}$, and the number of intracellular bacteria (shown as Colony Forming Unit, CFU) was determined. Data are presented as means \pm SEM of three independent experiments.
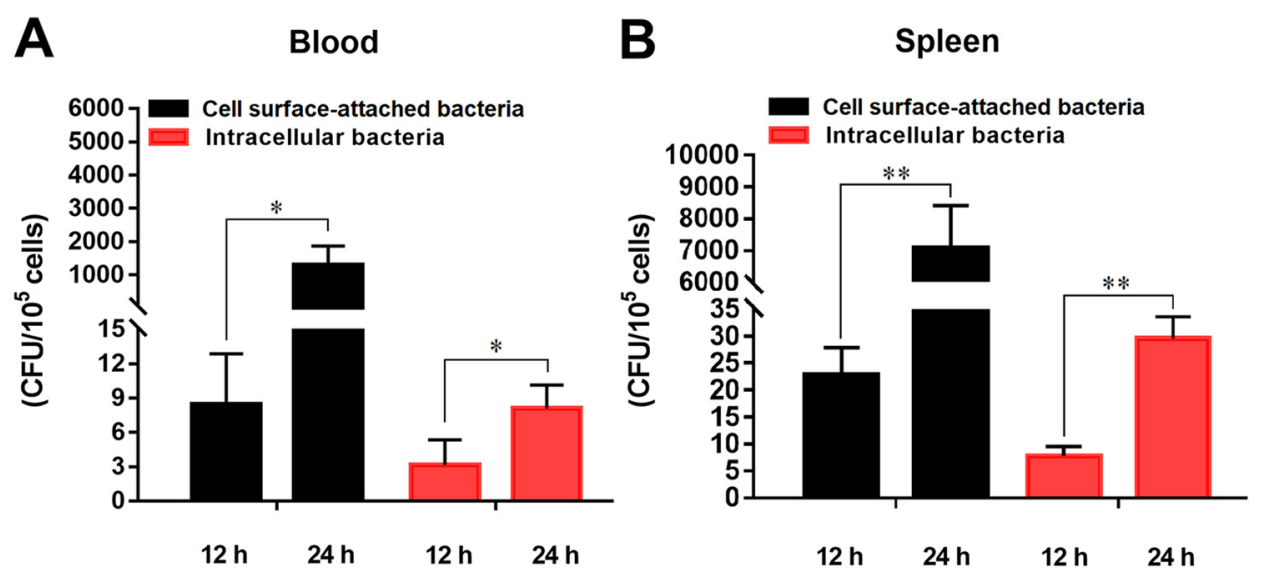

Figure 2. In vivo infection of Edwardsiella tarda in flounder blood and spleen erythrocytes. Flounder were infected with or without (control) E. tarda for $12 \mathrm{~h}$ and $24 \mathrm{~h}$, and erythrocytes were collected from blood (A) and spleen (B). The cell surface-attached and intracellular E. tarda were determined and shown as Colony Forming Unit (CFU). Data are presented as means \pm SEM of three independent experiments. * $p<0.05 ;{ }^{* *}, p<0.01$.

\subsection{RNA-seq of the Spleen Erythrocytes from E. tarda-Infected and Uninfected Flounder}

To examine E. tarda-induced transcription profiles in erythrocytes, three libraries were constructed with the RNAs from the spleen erythrocytes of $E$. tarda-infected flounder; similarly, three libraries were constructed with the RNAs from the spleen erythrocytes of the uninfected control fish. The six libraries were sequenced, and the data were summarized in Table 1. An average 44,186,824 raw reads were obtained, $99.25 \%$ of which passed the quality filtering process. After removing ribosomal RNAs, a mean number of 43,858,206 filtered clean reads was obtained from each library, and $82.87 \%-86.32 \%$ of the clean reads were mapped to the flounder genome. A total of 21,398 genes were detected. 
Table 1. Quality of RNA sequencing. C, control group; E, E. tarda-infected group. Each group was triplicated and shown as $-1,-2$, and -3 .

\begin{tabular}{llllll}
\hline Samples & $\begin{array}{l}\text { Read Length } \\
\text { (bp) }\end{array}$ & Raw Reads & Clean Reads & $\begin{array}{l}\text { Clean Read } \\
\text { Ratio (\%) }\end{array}$ & $\begin{array}{l}\text { Mapped Read } \\
\text { Ratio (\%) }\end{array}$ \\
\hline C-1 & 150 & $52,745,248$ & $52,367,850$ & 99.28 & 86.32 \\
C-2 & 150 & $39,343,878$ & $39,031,230$ & 99.21 & 85.97 \\
C-3 & 150 & $52,836,746$ & $52,477,326$ & 99.32 & 85.25 \\
E-1 & 150 & $38,019,958$ & $37,735,932$ & 99.25 & 85.49 \\
E-2 & 150 & $40,950,324$ & $40,635,040$ & 99.23 & 84.35 \\
E-3 & 150 & $41,224,792$ & $40,901,860$ & 99.22 & 82.87 \\
\hline
\end{tabular}

\subsection{Identification of Differentially Expressed Genes (DEGs) Induced by E. tarda}

DEGs were identified by the fold change of the gene expression level $\left(\log _{2}|\mathrm{FC}|>1\right)$ and a false discovery rate (FDR) (FDR $<0.05)$. Compared to the control group, the $E$. tarda-infected group exhibited 1720 DEGs, 928 and 792 of which were up- and downregulated, respectively. The distributions of the DEGs are shown in Figure 3. To verify the DEGs detected by RNA-seq, 12 DEGs were examined for expression using qRT-PCR. The results showed that the expression trends of the DEGs were in good agreement with that of RNA-seq (Figure S2).

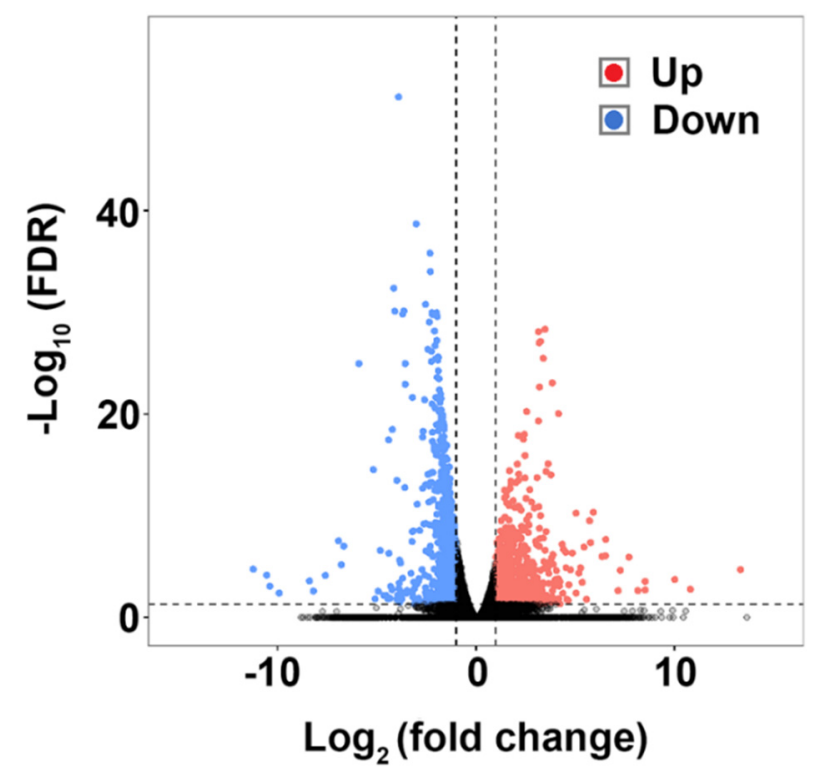

Figure 3. Volcano plot showing the distributions of the differentially expressed genes (DEGs). Each dot represents a gene. Red and blue dots represent up- and downregulated DEGs, respectively.

\subsection{GO and KEGG Enrichment Analysis of the DEGs}

GO enrichment analysis indicated that the 1720 DEGs were classified into three main categories: biological process (BP), cellular component (CC), and molecular function (MF). The top 20 significantly enriched GO terms (level-2) in these three categories are shown in Figure 4. Based on the values of rich factor, the top three GO terms in the category of BP were all related to antigen process and presentation, and the other terms associated with immunity were also highly represented in the immune system process (Figure 4A). In the category of MF, the immune related term of transporter associated with antigen processing (TAP) binding ranked top one, while metalloproteinase associated activity (metalloexopeptidase and metallopeptidase activities) ranked top two and three (Figure 4B). In the category of $\mathrm{CC}$, the top three GO terms based on rich factor were ribosome, organelle inner membrane, and organelle envelope (Figure $4 \mathrm{C}$ ). 


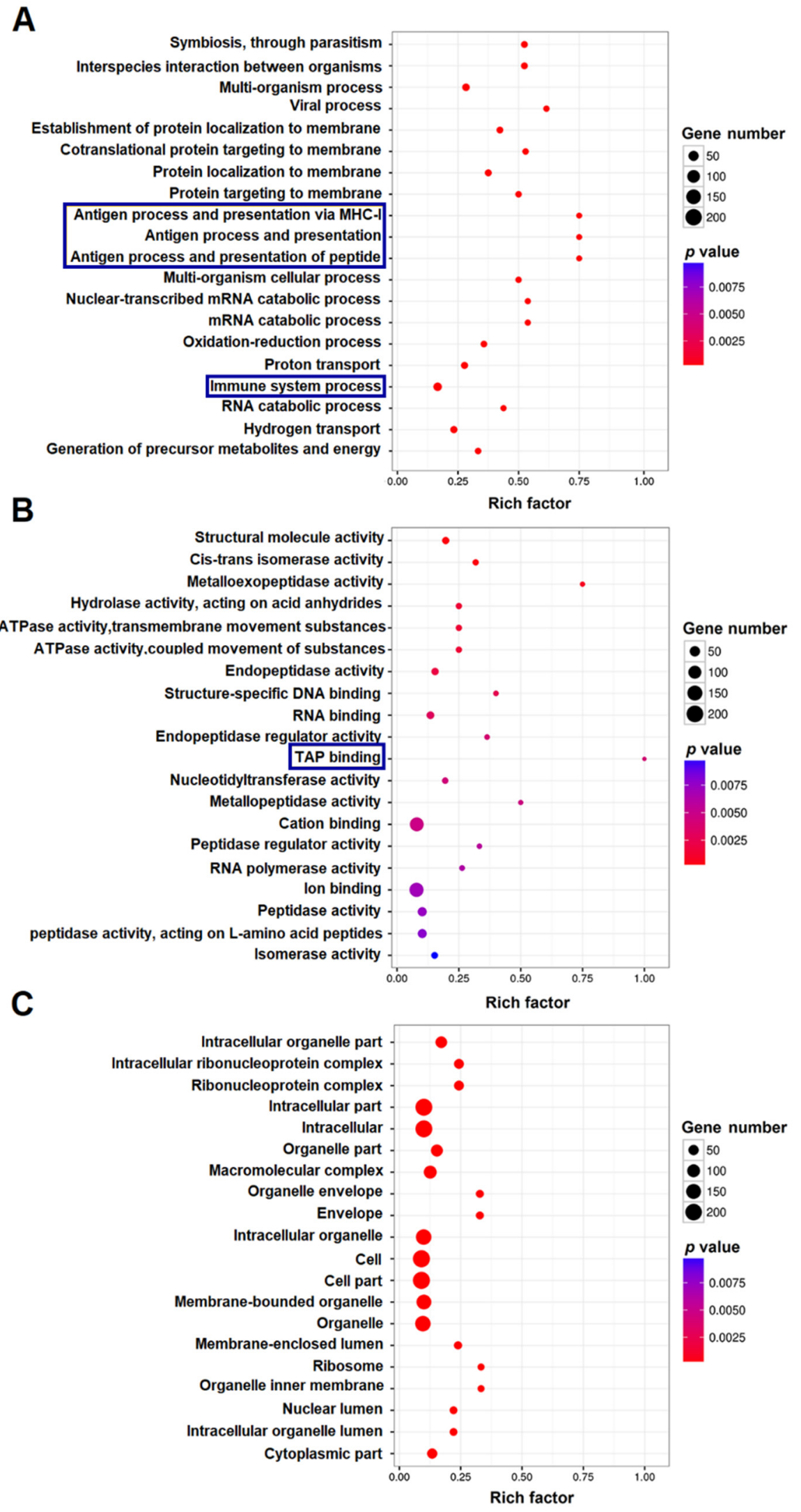

Figure 4. Gene Ontology (GO) enrichment analysis of differentially expressed genes (DEGs). Distribution of the top 20 (level-2) GO terms significantly enriched in the categories of biological process (A), molecular function (B), and cellular component (C) are shown. The immune related genes in $(\mathbf{A}, \mathbf{B})$ are boxed in blue. 
To further understand the biological functions of the DEGs, KEGG enrichment analysis was performed. DEGs of 12 immune-related pathways significantly enriched by KEGG analysis are shown in Table 2. These pathways included an intestinal immune network for IgA production, cytokine-cytokine receptor interaction, antigen processing and presentation, spliceosome, hematopoietic cell lineage, C-type lectin receptor signaling pathway, IL-17 signaling pathway, NOD-like receptor signaling pathway, NF-kappa B signaling pathway, Toll-like receptor signaling pathway, cytosolic DNA-sensing pathway, and JAK-STAT signaling pathway. In addition to these immune pathways, the terms of various diseases and infections, including systemic lupus erythematosus, graft-versus-host disease, Parkinson's disease, Huntington's disease, Alzheimer's disease, non-alcoholic fatty liver disease, autoimmune-thyroid disease, measles, influenza A, and Epstein-Barr virus infection, together with allograft rejection and oxidative phosphorylation were also highly represented based on rich factor (Figure S3).

Table 2. Summary of the 12 significantly enriched KEGG pathways related to immunity.

\begin{tabular}{lllc}
\hline \multicolumn{1}{c}{ Pathway } & DEG Number & Rich Factor & $p$-Value \\
\hline Intestinal immune network for IgA production & 8 & 0.211 & 0.008804 \\
Cytosolic DNA-sensing pathway & 10 & 0.196 & 0.006066 \\
Antigen processing and presentation & 9 & 0.173 & 0.020065 \\
Spliceosome & 25 & 0.169 & 0.000232 \\
Hematopoietic cell lineage & 12 & 0.167 & 0.010609 \\
C-type lectin receptor signaling pathway & 24 & 0.160 & 0.000698 \\
IL-17 signaling pathway & 13 & 0.159 & 0.012083 \\
NOD-like receptor signaling pathway & 20 & 0.143 & 0.007153 \\
NF-kappa B signaling pathway & 15 & 0.138 & 0.025076 \\
Toll-like receptor signaling pathway & 16 & 0.132 & 0.029570 \\
Cytokine-cytokine receptor interaction & 27 & 0.123 & 0.015126 \\
JAK-STAT signaling pathway & 22 & 0.119 & 0.036321 \\
\hline
\end{tabular}

\subsection{Construction of the Interaction Network Formed by Immune DEGs and Identification of the Hub Genes}

One hundred and eleven DEGs significantly enriched by KEGG analysis were used to construct the immune-related protein interaction network. Ninety-one DEGs (Table S2) turned out to exhibit interactions with each other and form interactive networks (Figure 5). These DEGs were involved in 12 immune related pathways, ranging from pathogen sensing to antigen processing, signal transduction, and effector production (Figure 6). To identify hub genes in the networks, the threshold of $\log _{2} \mid$ fold change| of $>2$ and multiple interaction degree of $>3$ was further set. As a result, 21 hub DEGs of the networks were identified (Table 3). Most of the hub genes were dramatically upregulated, in particular IL-10 and suppressor of cytokine signaling 1 (SOCS1), which exhibited the highest levels of upregulation (18.6 and 12.6 folds, respectively) and also high levels of interactions with other DEGs (interactive degree of 22 and 29, respectively). Tumor necrosis factor receptor superfamily member $1 \mathrm{~A}$, mast/stem cell growth factor receptor kita-like isoform X1, and transcription factor RelB also exhibited a more than 10-fold change in expression and extensive interactions with other genes. Other upregulated hub genes displayed an expressional fold change of between 4.23 to 9.5. Only three hub genes were downregulated, with a fold change of between 4.04 to 4.74 (Table 3). 


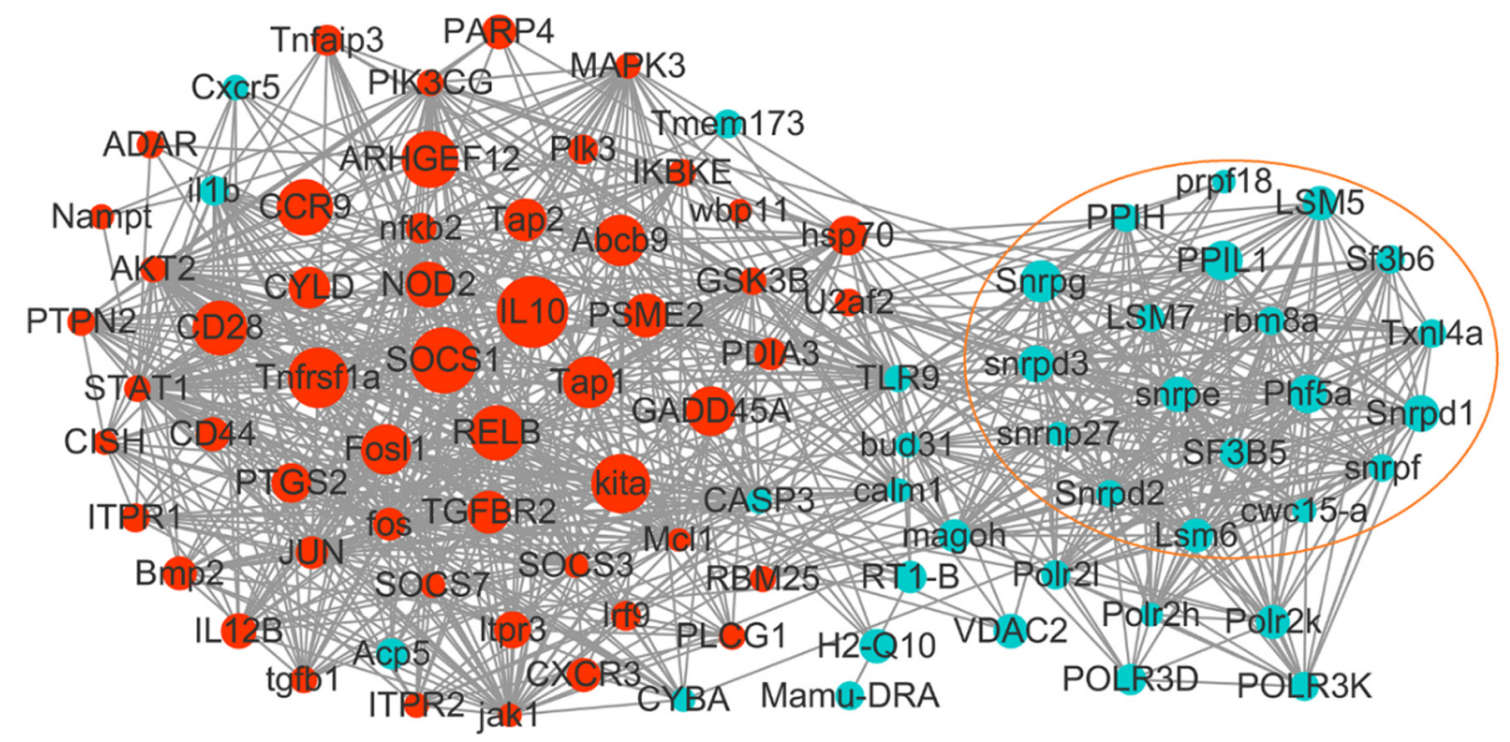

Figure 5. The interaction network formed by immune related DEGs. The nodes in the network represent DEGs, and the lines connecting different nodes denote interactions between the DEGs. Red and blue nodes represent up- and downregulated DEGs, respectively. Node size indicates the $\log _{2}|\mathrm{FC}|$ of the DEGs. The DEGs involved in spliceosome and splicing are enclosed in an orange lined circle.

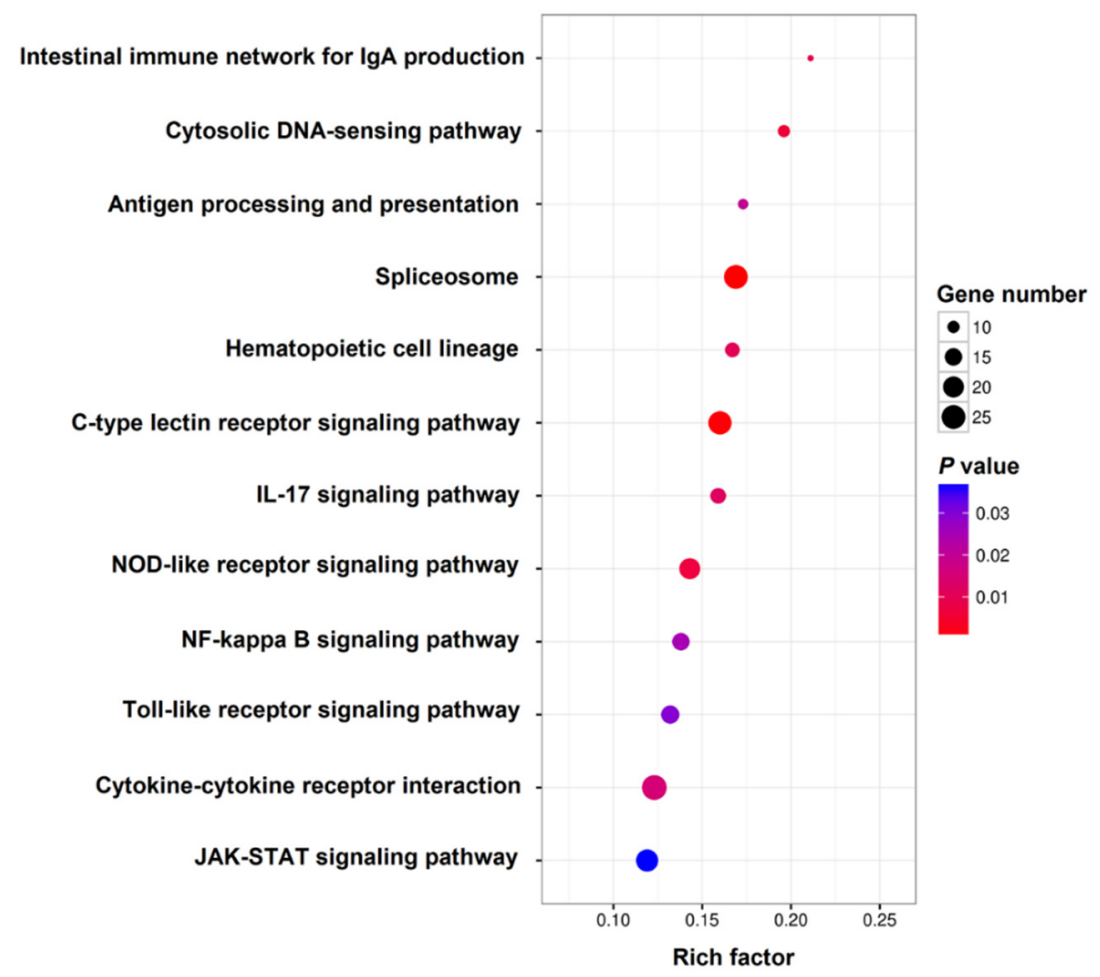

Figure 6. The DEGs that form interactive networks belong to 12 immune related pathways by KEGG analysis. The color and size of the dots indicate $p$-value and DEG number, respectively. 
Table 3. Summary of the 21 hub DEGs. The "+" and "-" symbols before the fold change number indicate up- and downregulation, respectively.

\begin{tabular}{llll}
\hline $\begin{array}{l}\text { Gene } \\
\text { Name }\end{array}$ & Description & $\begin{array}{l}\text { Interactive } \\
\text { Degree }\end{array}$ & Fold Change \\
\hline IL10 & Interleukin-10 & 22 & +18.63 \\
SOCS1 & Suppressor of cytokine signaling 1 & 29 & +12.61 \\
TNFASF1A & Tumor necrosis factor receptor superfamily member 1A & 16 & +11.19 \\
KITA & Mast/stem cell growth factor receptor kita-like isoform X1 & 33 & +10.44 \\
RELB & Transcription factor RelB homolog isoform X1 & 40 & +10.43 \\
ARHGEF12 & Rho guanine nucleotide exchange factor 12 & 7 & +9.50 \\
CD28 & T cell specific surface glycoprotein CD28 & 14 & +8.58 \\
TAP1 & Antigen peptide transporter 1 & 13 & +7.42 \\
ABCB9 & ATP-binding cassette subfamily B member 9 & 13 & +7.34 \\
FOSL1 & Fos-related antigen 1 & 21 & +6.96 \\
GADD45A & Growth arrest and DNA damage protein GADD45 alpha-like & 11 & +6.72 \\
NOD2 & Nucleotide-binding oligomerization domain containing 2 & 15 & +5.72 \\
PSME2 & Proteasome activator complex subunit 2 & 11 & +5.23 \\
TGFBR2 & TGF-beta receptor type 2 & 10 & +4.96 \\
TAP2 & Antigen peptide transporter 2 & 11 & +4.93 \\
SNRPG & Small nuclear ribonucleoprotein polypeptide G & 25 & -4.74 \\
CYLD & Ubiquitin carboxyl-terminal hydrolase CYLD-like & 7 & +4.69 \\
PTGS2 & Prostaglandin G/H synthase 2 & 16 & +4.27 \\
PPIL1 & Peptidyl-prolyl cis-trans isomerase-like 1 & 20 & -4.27 \\
HSP70 & Heat shock 70 KDA protein & 28 & +4.23 \\
PHF5A & PHD finger-like domain-containing protein 5A & 23 & -4.04 \\
\hline
\end{tabular}

\section{Discussion}

In this study, we performed both in vitro and in vivo analyses to examine the infectivity of $E$. tarda in flounder RBCs. In vitro infection showed that $E$. tarda was capable of intracellular replication inside RBCs. Consistently, in vivo infection indicated that $E$. tarda was able to invade into the erythrocytes of flounder spleen. These results are in line with the previous reports that showed E. tarda is an intracellular pathogen in fish and mammalian models [26,28]. To examine the immune response of RBCs elicited by E. tarda, transcriptome analysis was performed, which identified 1720 DEGs in the spleen RBCs of E. tarda-infected flounder, indicating a global influence of $E$. tarda on the gene expression of RBCs. It is of note that the top terms in the GO categories of biological process and molecular function were enriched highly with DEGs of antigen process and presentation, and the top terms of the KEGG were enriched predominately with DEGs of immunity, diseases, and infection, indicating an intensive induction of immune defense genes. Ninety-one immune DEGs were found to form high degrees of interactions with each other and constitute a complicated network. Twenty-one hub genes were further identified from the network, which were dramatically regulated by E. tarda. The potential functional significances of the key hub genes are discussed below.

\subsection{Genes Involved in NLRs-Mediated Pathogen Recognition and Downstream NF-кB Activation}

Pathogen recognition mediated by PRRs is the first step of host immune response. NLRs are a family of intracellular PRRs that recognize intracellular pathogens and activate downstream signaling events [29-31]. NOD2, a prototype NLR, has been shown to be an intracellular recognition receptor that can sense the presence of Gram-negative and Gram-positive bacteria in the cytosolic compartment by recognizing muramyl dipeptide on the bacterial cell wall peptidoglycan [32-35]. In our study, we found that NOD2 interacted with 15 key immune-related genes and was upregulated by 5.72 -fold after $E$. tarda challenge, suggesting that $E$. tarda infection activated the NOD2-mediated NLRs signaling pathway. In mammals, NOD2 is a positive regulator of NF- $\mathrm{BB}$ and, through NF- $\mathrm{kB}$, induces transcription and production of inflammatory mediators [36-40]. In fish, NOD2-induced NF- $\mathrm{kB}$ activation has been reported in zebrafish and mrigal [41,42]. In our study, consistent with the upregulated NLRs pathway, 
NF- $\mathrm{BB}$ pathway genes were also significantly upregulated as indicated by the 10.43- and 2.84-fold increase in the expression of RELB and NFKB2 (NF- $\mathrm{KB}$ p100 subunit), respectively (Table 3, Table S2). The NF-KB family of transcription factors contain several members, including RELB and p100/p52 (NFKB2) that form various homo- or heterodimeric complexes and bind to the kappa-B sites in their target genes, leading to activation or repression of the transcription of the target genes. The markedly upregulated expression of RELB and NFKB2 suggests that the NF- $\mathrm{KB}$ signaling was active in flounder RBCs during E. tarda infection, which was probably at least in part due to the activation of the NLRs pathway. In the interaction networks, NOD2 displayed interactions with NFKB2 and other 14 key immune-related genes, which further supported a signaling link between the NLRs pathway and the NF-KB pathway in the context of E. tarda infection.

\subsection{Genes Involved in Antigen Processing and Presentation}

Antigen processing and presentation convert pathogenic antigens into immunogenic peptides, which are subsequently exposed on the cell surface and recognized by immunocompetent cells [43,44]. In this study, four hub genes (TAP1, TAP2, ABCB9, and PSME2) were significantly enriched in the category of antigen processing and presentation. In mammals, TAP1 and TAP2 function to transport antigen peptides into the lumen of the endoplasmic reticulum, where the peptides are loaded onto major histocompatibility complex (MHC) class I molecules [45,46]. ABCB9 is similar to TAP1 and TAP2 and shares high sequence homology with the latter [45]. PSME2 is known to facilitate antigen process and presentation by strengthening the ability of the 20S proteasome to produce more peptides to bind the MHC-I molecules [47,48]. In our study, TAP1, TAP2, ABCB9, and PSME2 were all exceedingly upregulated and displayed high levels (degree of 11 and 13) of interactions with other DEGs. These results suggest that flounder $\mathrm{RBC}$ s were able to elicit the process of antigen processing and presentation following E. tarda challenge.

\subsection{Genes Involved in Anti-Inflammatory Responses}

Inflammation is a protective reaction of the host to clear detrimental stimulations, including pathogens [49]. Anti-inflammatory factors play important roles in the control of inflammatory responses [50-55]. These factors include $I L-10$ and members of the SOCS family $[51,55]$. In this study, IL-10 and SOCS1 were identified as the top one and top two hub genes that exhibited the highest fold changes (18.63 and 12.61, respectively) in expression upon E. tarda infection. IL-10 is one of the most important anti-inflammatory cytokines in humans and inhibits the expression of TNF $\alpha$, IL-1, IL-6, IL-8, and other pro-inflammatory cytokines [55-57]. IL-10 also inhibits MHC-II expression and antigen presentation $[58,59]$. Similarly, in fish, IL-10 suppresses the expression of pro-inflammatory cytokines in carp, amberjack, mandarin fish, Atlantic cod, and goldfish [59-63]. In mammals, SOCS1 is induced by a wide range of cytokines and negatively regulates a number of immune signaling pathways $[64,65]$. In fish, SOCS1 is known to inhibit the type I/type II IFN signaling pathways in Atlantic salmon and suppress the JAK-STAT signaling pathway in miiuy croaker $[66,67]$. The dramatically elevated expressions of IL-10 and SOCS1 in the RBCs of E. tarda-infected flounder suggest inhibition of the inflammatory response in these cells.

In addition to $I L-10$ and the SOCS1, other DEGs, including PTGS2, TGFBR2, and CYLD, involved in anti-inflammation were also identified among the hub genes in our study. PTGS2 plays a key role in the generation of prostaglandin E2 (PGE2) that exerts anti-inflammatory function $[52,68]$. In mammals, PGE2 inhibits the production of pro-inflammatory molecules and enhances the secretion of anti-inflammatory cytokines, such as $I L-10$ [69]. TGFBR2 functions via TGF- $\beta 1$, which mainly regulates immune suppression/tolerance and anti-inflammatory responses [70-72]. CYLD is a deubiquitinating enzyme that removes polyubiquitin chains from target proteins such as NF- $\mathrm{KB}, \mathrm{BCL} 3$, and TRAFs [73,74]. CYLD has also been shown to promote anti-inflammation [75,76]. In fish, PGE2 is known to induce IL-10, suppress the expression of TNF $\alpha$ and MHC-II, and inhibit the immune response of neutrophils [77-85]. TGF- $\beta 1$ has been reported to block LPS- and TNF $\alpha$-induced activation of macrophages and peripheral 
blood lymphocytes in goldfish and grass carp $[86,87]$. The greatly heightened expressions of $I L-10$, SOCS1, PTGS2, TGFBR2, and CYLD, as well as their high degrees of interactions in the networks, observed in our study indicate intense and extensive inductions of anti-inflammatory responses in flounder RBCs following E. tarda challenge, which might be the result of bacterial manipulation of the host's immune reactions to facilitate the invasion and survival of the pathogen in the host.

\subsection{Genes Involved in Spliceosome and Splicing}

In eukaryotic organisms, most genes are firstly expressed as precursor mRNA (pre-mRNA) and then converted to mRNA by splicing [88]. This process is catalyzed by the spliceosome. In our study, 19 key DEGs were significantly enriched in the spliceosome and splicing pathway (Figure 5). Among these genes, SNRPG, PPIL1, and PHF5A were identified as hub genes. In mammals, SNRPG is a core component of the spliceosome small nuclear ribonucleoproteins, and PHF5A is also a part of the spliceosome and acts as a DNA binding protein [88,89]. PPIL1 participates in pre-mRNA splicing and is recruited into the spliceosome at the stage of complex B formation [88]. In our study, SNRPG, PPIL1, and PHF5A were all significantly downregulated by 4.04- to 4.74-fold in E. tarda-infected RBCs, which is in line with a previous report showing that spliceosome-associated genes were mostly downregulated in rainbow trout RBCs exposed to VHSV [9]. However, in another report of rock bream RBCs exposed to rock bream iridovirus (RBIV), spliceosome-related proteins were mostly upregulated [20]. These results indicate pathogen-specific regulations of spliceosome activity. The strong downregulation in the expression of multiple spliceosome genes observed in our study suggests a systematic inhibition of mRNA processing, which could be a strategy of E. tarda to interfere with the expression of the host genes required for pathogen clearance.

\section{Materials and Methods}

\subsection{Japanese Flounder}

Clinically healthy Japanese flounder (average $250 \mathrm{~g}$ ) were purchased from a local fish farm in Qingdao, China. The fish were acclimatized in the laboratory for one week, during which time the fish were maintained at $\sim 20{ }^{\circ} \mathrm{C}$ in aquariums and fed daily with commercial food as reported previously $[27,90]$. Before the experiment, the fish were verified to be clinically healthy as reported previously [91]. In experiments requiring tissue collection, the fish were euthanized with tricaine methane sulfonate (Sigma, St. Louis, MO, USA) to minimize suffering as described previously [92]. The study with live fish was approved by the Ethics Committee of Institute of Oceanology, Chinese Academy of Sciences (permit No. MB1807) on July 20, 2018.

\subsection{Isolation of Erythrocytes from the Blood and Spleen of Flounder}

Blood was collected from Japanese flounder as reported previously [27]. Briefly, fish were euthanized with tricaine methane sulfonate (Sigma, St. Louis, MO, USA), and the blood was collected from the caudal vein and diluted with PBS (Solarbio, Beijing, China) containing 10 units/mL heparin (Solarbio, Beijing, China). The diluted blood was placed on the top of $1.070 \mathrm{~g} / \mathrm{mL}$ Percoll (GE Healthcare, Uppsala, Sweden) and centrifuged at $400 \times g$ for $10 \mathrm{~min}$. Red blood cell pellet was collected and resuspended with RPMI-1640 medium (Gibco, Waltham, MA, USA). The cell suspension was purified with $1.070 \mathrm{~g} / \mathrm{mL}$ Percoll for $2-3$ times to obtain high purity RBCs. The purified RBCs were added into RPMI-1640 medium containing 10\% calf serum (Gibco, Carlsbad, CA, USA), $100 \mathrm{U} / \mathrm{mL}$ penicillin (Solarbio, Beijing, China), 100 mg/mL streptomycin (Solarbio, Beijing, China), and $50 \mu \mathrm{g} / \mathrm{mL}$ gentamicin (Solarbio, Beijing, China). To isolate spleen RBCs, spleen tissues were collected from the fish aseptically and gently ground in a cell culture dish (Corning, Jiangsu, China) containing 10 units/mL heparin (Solarbio, Beijing, China). RBCs were then isolated and purified as described above. 


\subsection{In Vitro Infection of E. tarda in RBCs}

Examination of the intracellular replication of E. tarda was carried out as reported previously [93]. Briefly, RBCs were incubated with E. tarda as described above at a MOI of 10. After $3 \mathrm{~h}$ of incubation, the RBCs were collected by centrifugation at $4{ }^{\circ} \mathrm{C}$ and gently washed twice with PBS. The bacteria attached to the surface of RBCs were killed by adding gentamicin $(200 \mu \mathrm{g} / \mathrm{mL})$ and incubation at $20^{\circ} \mathrm{C}$ for $2 \mathrm{~h}$. The cells were washed two times with PBS and cultured in RPMI-1640 medium containing $10 \mu \mathrm{g} / \mathrm{mL}$ gentamicin for $0 \mathrm{~h}, 2 \mathrm{~h}$, or $4 \mathrm{~h}$. At each time point, $1 \%$ Triton X-100 was added to lyse the $\mathrm{RBCs}$, and the lysate was diluted and plated onto LB agar plates. After overnight incubation at $28^{\circ} \mathrm{C}$, the colonies that appeared on the plates were counted. The experiment was performed three times.

\subsection{In Vivo Infection of E. tarda in Flounder}

E. tarda was suspended in PBS to a final concentration of $5 \times 10^{8}$ colony forming units (CFU) $\mathrm{mL}^{-1}$. Flounder were randomly divided into two groups. The experimental group was intraperitoneally injected with $200 \mu \mathrm{L}$ of the above bacterial suspension per fish, and the control group was injected with the same volume of PBS. At $12 \mathrm{~h}$ and $24 \mathrm{~h}$ post-infection (hpi), blood and spleen tissues were taken aseptically from the fish ( 3 individuals at each time point from each group) and isolated and purified as described above. The purified RBCs were divided into two parts and used to determine the numbers of cell surface-attached E. tarda and intracellular E. tarda. For this purpose, one part of the PBCs was directly lysed, while the other part was firstly incubated with gentamicin $(200 \mu \mathrm{g} / \mathrm{mL})$ for $2 \mathrm{~h}$ to kill extracellular E. tarda and then lysed. The cell lysates from the two parts were each plated onto LB agar plates, which were incubated as described above, and the colony numbers were counted. The number of cell surface-attached E. tarda was obtained by subtracting the bacterial number in the second part of lysate from the bacterial number in the first part of lysate.

\subsection{RNA Sequencing Library Construction and Sequencing}

Flounder were divided into two groups and infected with E. tarda or treated with PBS (control group) as described above. At 24 hpi, RBCs were collected from the spleen of the fish (6 fish from each group) and purified as described above. The purified RBCs were inspected by light microscopy to confirm purity (Figure S1). For transcriptome analysis, six RNA-seq libraries (triplicates of the infected group ( 2 fish/group) and the uninfected control group (2 fish/group)) were constructed using the purified RBCs. Total RNA extraction was performed using Trizol RNA extraction reagent (Invitrogen, CA, USA) following the manufacturer's protocol. The quality of the purified RNA was assessed using Agilent 2100 Bioanalyzer. RNA integrity was determined by agarose gel electrophoresis. The sequencing libraries were constructed according to the Illumina's standard protocol as previously reported [94]. Briefly, mRNA was enriched from total RNA using Oligo (dT) beads (Qiagen, Hilden, Germany) and fragmented into short fragments, which were reverse transcribed into first-strand cDNA. Second-strand cDNA was then synthesized with DNA polymerase I (Thermo Scientific, Waltham, MA, USA), dNTP, and RNase H. The cDNA fragments were purified, end repaired and added with poly (A), and ligated to Illumina sequencing adapters. Finally, the libraries were sequenced with the Illumina Hiseq-novaseq 6000 platform by the Gene Denovo Biotechnology Co. (Guangzhou, China).

\subsection{Data Preprocessing}

The raw reads of the libraries were filtered by removing low-quality reads, including reads containing nucleotide with a $Q$ quality score of $\leq 20$, reads containing adapters, and reads with undetermined nucleotides larger than $10 \%$, before mapping to the ribosome RNA (rRNA) database in Bowtie 2 (v2.2.8) [95]. The rRNA-mapped reads were removed, and the remaining reads were mapped to the Japanese flounder genome sequence (GenBank project accession PRJNA369269) with TopHat2 (v2.0.3.12) [96]. The reconstruction of the transcripts was conducted with Cufflinks (v2.2.1) [97]. The abundance of each transcript was quantified with the software RSEM v1.2.19 [98]. The gene 
expression level was normalized by using the FPKM (Fragments Per Kilobase of transcript per Million mapped reads) method [99].

\subsection{Identification, Validation, and Functional Enrichment Analysis of Differentially Expressed Genes (DEGs)}

Differential expression analysis was carried out using the R package edgeR (v3.12.1) (http://www. r-project.org/). The exact negative binomial test [100] was applied to perform pairwise comparison between the infected group and the control group. Transcripts with a false discovery rate (FDR) of $<0.05$ and an expression fold change (FC) of $>2\left(\log _{2}|\mathrm{FC}|>1\right)$ were considered as DEGs. The expressions of 12 DEGs were validated by quantitative real-time reverse transcription-PCR (qRT-PCR) as reported previously $[26,101]$. Briefly, gene-specific primers were designed using Primer designer of NCBI (https://www.ncbi.nlm.nih.gov) and listed in Table S1. qRT-PCR was carried out in a QuantStudio 3 Real-Time PCR Systems (Thermo Fisher Scientific, CA, USA) using SYBR Premix Ex Taq II (Takara, Dalian, China) following the manufacturer's protocol. The melting curve analysis was conducted to confirm that the specific PCR product was amplified and detected. The expression levels of the target genes were analyzed using the comparative threshold cycle method $(2-\Delta \Delta \mathrm{CT})$ with $\beta$-actin as an internal reference [2]. The DEGs were subjected to Gene Ontology (GO) functional analysis and Kyoto Encyclopedia of Genes and Genomes (KEGG) pathway enrichment based on GO database (http://geneontology.org) and KEGG database (http://www.genome.jp/kegg/). A $p$-value of $<0.05$ was set as a threshold to identify significantly enriched GO terms and KEGG pathways using hypergeometric test.

\subsection{Construction of Interaction Network and Hub Genes Identification}

The immune-related DEGs in Table 2 were used to construct protein-protein interaction (PPI) networks using the String software (http://string-db.org/) [102] as reported previously [26,101]. The hub genes were further identified from PPI networks based on the following degrees: $\log _{2}|F C|>2$ and PPI $>3$.

\subsection{Statistical Analysis}

All experiments were performed three times or in triplicate, and graphic representation and statistical analyses were carried out with Graphpad Prism 6 (www.graphpad.com). Data were analyzed with the Student's $t$-test, and statistical significance was defined as $p<0.05$.

\section{Conclusions}

In this study, transcriptome analysis reveals a large scale immune response induced by E. tarda in flounder RBCs. A core set of DEGs significantly enriched to 12 immune-related pathways were found to form complicated interaction networks. The hub genes of the networks are involved in key immune processes that, for some, promote pathogen elimination and, for some others, may facilitate pathogen infection. These results indicate that flounder RBCs are capable of mounting profound immune responses in an effort to fight against $E$. tarda, but some of the immune responses are likely manipulated by $E$. tarda to the advantage of optimum bacterial invasion. Our results add new insights into the immune role of flounder RBCs in association with bacterial infection and provide a genetic basis for future study of the immune mechanisms of flounder RBCs. In future studies, it should be interesting to compare the immune responses of RBCs in different tissues and see whether there is any tissue-specificity in the response.

Supplementary Materials: The following are available online at http://www.mdpi.com/1422-0067/21/9/3094/s1, Table S1. List of the primers used for qRT-PCR. Table S2. List of the 91 immune-related DEGs used in Figure 6. Figure S1. Microscopic observation of purified flounder spleen red blood cells (RBCs). Figure S2. Comparison of the relative expressions of selected DEGs by qRT-PCR and RNA-Seq. The relative expression levels of 12 DEGs were determined by qRT-PCR, and the results are compared with that of RNA-Seq. Red dotted line represents the 
control group. Figure S3. The top 20 enriched KEGG pathways of differentially expressed genes (DEGs). The color and size of the dots indicate $p$-value and DEG number, respectively.

Author Contributions: Conceptualization, L.S.; methodology, B.S.; formal analysis, B.S. and X.N.; investigation, B.S. and X.L.; writing — original draft preparation, B.S.; writing-review and editing, L.S.; supervision, L.S.; funding acquisition, L.S. All authors have read and agreed to the published version of the manuscript.

Funding: This research was supported by the grants of the Marine S \& T Fund of Shandong Province for Pilot National Laboratory for Marine Science and Technology (Qingdao) (2018SDKJ0302-2), the National Key R \& D Project of China (2018YFD0900500), and the Taishan Scholar Program of Shandong Province.

Conflicts of Interest: The authors declare no conflict of interest.

\section{References}

1. Nombela, I.; Ortega-Villaizan, M.D.M. Nucleated red blood cells: Immune cell mediators of the antiviral response. PLoS Pathog. 2018, 14, e1006910. [CrossRef]

2. Dahle, M.K.; Wessel, Ø.; Timmerhaus, G.; Nyman, I.B.; Jorgensen, S.M.; Rimstad, E.; Krasnov, A. Transcriptome analyses of atlantic salmon (Salmo salar L.) erythrocytes infected with piscine orthoreovirus (PRV). Fish Shellfish Immunol. 2015, 45, 780-790. [CrossRef] [PubMed]

3. Moras, M.; Lefevre, S.D.; Ostuni, M.A. From Erythroblasts to Mature Red Blood Cells: Organelle Clearance in Mammals. Front. Physiol. 2017, 8, 1076. [CrossRef] [PubMed]

4. Glomski, C.A.; Tamburlin, J.; Chainani, M. The phylogenetic odyssey of the erythrocyte. III. Fish, the lower vertebrate experience. Histol. Histopathol. 1992, 7, 501-528. [PubMed]

5. Fernandes, J.M.; Smith, V.J. Partial purification of antibacterial proteinaceous factors from erythrocytes of Oncorhynchus mykiss. Fish Shellfish Immunol. 2004, 16, 1-9. [CrossRef]

6. Passantino, L.; Altamura, M.; Cianciotta, A.; Patruno, R.; Passantino, G.F. Fish immunology. i. binding and engulfment of Candida albicans by erythrocytes of rainbow trout (Salmo gairdneri richardson). Immunopharmacol. Immunotoxicol. 2002, 24, 665-678. [CrossRef]

7. Morera, D.; Roher, N.; Ribas, L.; Balasch, J.C.; Doñate, C.; Callol, A.; Boltaña, S.; Roberts, S.; Goetz, G.; Goetz, F.W.; et al. RNA-Seq reveals an integrated immune response in nucleated erythrocytes. PLoS ONE 2011, 6, e26998. [CrossRef]

8. Workenhe, S.T.; Kibenge, M.J.; Wright, G.M.; Wadowska, D.W.; Groman, D.B.; Kibenge, F.S. Infectious salmon anaemia virus replication and induction of alpha interferon in atlantic salmon erythrocytes. Virol. J. 2008, 5, 36. [CrossRef]

9. Nombela, I.; Puente-Marin, S.; Chico, V.; Villena, A.; Carracedo, B.; Ciordia, S.; Mena, M.; Mercado, L.; Perez, L.; Coll, J.; et al. Identification of Diverse Defense Mechanisms in Trout Red Blood Cells in Response to VHSV Halted Viral Replication. F1000 Res. 2018, 6, 1958. [CrossRef]

10. Nombela, I.; Carrion, A.; Puente-Marin, S.; Chico, V.; Mercado, L.; Perez, L.; Coll, J.; Ortega-Villaizan, M.D.M. Infectious pancreatic necrosis virus triggers antiviral immune response in rainbow trout red blood cells, despite not being infective. F1000 Res. 2017, 6, 1968. [CrossRef]

11. Nombela, I.; Lopez-Lorigados, M.; Salvador-Mira, M.E.; Puente-Marin, S.; Chico, V.; Ciordia, S.; Ortega-Villaizan, M.D.M. Integrated Transcriptomic and Proteomic Analysis of Red Blood Cells from Rainbow Trout Challenged with VHSV Point Towards Novel Immunomodulant Targets. Vaccine 2019, 7, 63. [CrossRef] [PubMed]

12. Chico, V.; Nombela, I.; Puente-Marín, S.; Ortega-Villaizan, M.D.M. Nucleated Red Blood Cells Contribute to the Host Immune Response Against Pathogens. In Immune Response Activation and Immunomodulation; Rajeev, K.T., Prakash, S.B., Eds.; IntechOpen: London, UK, 2018; p. 39, ISBN 978-1-78985-152-6.

13. Morera, D.; MacKenzie, S.A. Is there a direct role for erythrocytes in the immune response. Vet. Res. 2011, 42, 89. [CrossRef] [PubMed]

14. Wessel, Ø.; Olsen, C.M.; Rimstad, E.; Dahle, M.K. Piscine orthoreovirus (prv) replicates in atlantic salmon (Salmo salar L.) erythrocytes ex vivo. Vet. Res. 2015, 46, 26. [CrossRef] [PubMed]

15. Shen, Y.; Wang, D.; Zhao, J.; Chen, X. Fish red blood cells express immune genes and responses. Aquac. Fish. 2018, 3, 14-21. [CrossRef] 
16. Sarder, M.R.; Fischer, U.; Dijkstra, J.M.; Kiryu, I.; Yoshiura, Y.; Azuma, T.; Kollner, B.; Ototake, M. The MHC class I linkage group is a major determinant in the in vivo rejection of allogeneic erythrocytes in rainbow trout (oncorhynchus mykiss). Immunogenetics 2003, 55, 315-324. [CrossRef]

17. Dijkstra, J.M.; Kollner, B.; Aoyagi, K.; Sawamoto, Y.; Kuroda, A.; Ototake, M.; Nakanishi, T.; Fischer, U. The rainbow trout classical MHC class I molecule onmy-uba*501 is expressed in similar cell types as mammalian classical mhc class i molecules. Fish Shellfish Immunol. 2003, 14, 1-23. [CrossRef]

18. Puente-Marin, S.; Nombela, I.; Ciordia, S.; Mena, M.C.; Chico, V.; Coll, J.; Ortega-Villaizan, M.D.M. In silico functional networks identified in fish nucleated red blood cells by means of transcriptomic and proteomic profiling. Gene 2018, 9, 202. [CrossRef]

19. Puente-Marin, S.; Nombela, I.; Chico, V.; Ciordia, S.; Mena, M.C.; Coll, J.; Mercado, L.; Ortega-Villaizan, M.D.M. Rainbow trout erythrocytes ex vivo transfection with a DNA vaccine encoding VHSV glycoprotein G induces an antiviral immune response. Front. Immunol. 2018, 9, 2477. [CrossRef]

20. Jung, M.H.; Gras, V.C.; Ciordia, S.; Mena, M.C.; Jung, S.J.; Ortega-Villaizan, M.D.M. The Megalocytivirus RBIV Induces Apoptosis and MHC class I presentation in Rock Bream (Oplegnathus fasciatus) Red Blood Cells. Front. Immunol. 2019, 10, 160. [CrossRef]

21. Leung, K.Y.; Siame, B.A.; Tenkink, B.J.; Noort, R.J.; Mok, Y.K. Edwardsiella tarda-virulence mechanisms of an emerging gastroenteritis pathogen. Microbes Infect. 2012, 14, 26-34. [CrossRef]

22. Park, S.B.; Aoki, T.; Jung, T.S. Pathogenesis of and strategies for preventing Edwardsiella tarda infection in fish. Vet. Res. 2012, 43, 67. [CrossRef] [PubMed]

23. Matsuyama, T.; Kamaishi, T.; Ooseko, N.; Kurohara, K.; Iida, T. Pathogenicity of Motile and Non-motile Edwardsiella tarda to some Marine Fish. Fish Pathol. 2009, 40, 133-135. [CrossRef]

24. Li, M.F.; Sun, L.; Li, J. Edwardsiella tarda evades serum killing by preventing complement activation via the alternative pathway. Fish Shellfish Immunol. 2015, 43, 325-329. [CrossRef] [PubMed]

25. Ishibe, K.; Osatomi, K.; Hara, K.; Kanai, K.; Yamaguchi, K.; Oda, T. Comparison of the responses of peritoneal macrophages from Japanese flounder (Paralichthys olivaceus) against high virulent and low virulent strains of Edwardsiella tarda. Fish Shellfish Immunol. 2008, 24, 243-251. [CrossRef]

26. Li, H.L.; Sun, B.G.; Ning, X.H.; Jiang, S.; Sun, L. A Comparative Analysis of Edwardsiella tarda-Induced Transcriptome Profiles in RAW264. 7 Cells Reveals New Insights into the Strategy of Bacterial Immune Evasion. Int. J. Mol. Sci. 2019, 20, 5724. [CrossRef]

27. Sun, B.; Sun, Y.Y.; Li, X.P.; Jiang, S.; Sun, L. Particle and bacteria uptake by Japanese flounder (Paralichthys olivaceus) red blood cells: Size dependence and pathway specificity. Tissue Cell 2019, 61, 79-88. [CrossRef]

28. Zhou, Z.J.; Sun, L. Edwardsiella tarda-induced inhibition of apoptosis: A strategy for intracellular survival. Front. Cell Infect. Microbiol. 2016, 6, 76. [CrossRef]

29. Meylan, E.; Tschopp, J.; Karin, M. Intracellular pattern recognition receptors in the host response. Nature 2006, 442, 39-44. [CrossRef]

30. Philpott, D.J.; Girardin, S.E. Nod-like receptors: Sentinels at host membranes. Curr. Opin. Immunol. 2010, 22, 428-434. [CrossRef]

31. Rubino, S.J.; Selvanantham, T.; Girardin, S.E.; Philpott, D.J. Nod-like receptors in the control of intestinal inflammation. Curr. Opin. Immunol. 2012, 24, 398-404. [CrossRef]

32. Chang, M.; Wang, T.; Nie, P.; Zou, J.; Secombes, C.J. Cloning of two rainbow trout nucleotide-binding oligomerization domain containing 2 (NOD2) splice variants and functional characterization of the NOD2 effector domains. Fish Shellfish Immunol. 2011, 30, 118-127. [CrossRef]

33. Chen, W.Q.; Xu, Q.Q.; Chang, M.X.; Nie, P.; Peng, K.M. Molecular characterization and expression analysis of nuclear oligomerization domain proteins NOD1 and NOD2 in grass carp (Ctenopharyngodon idella). Fish Shellfish Immunol. 2010, 1, 18-29. [CrossRef] [PubMed]

34. Inohara, N.; Ogura, Y.; Fontalba, A.; Gutierrez, O.; Pons, F.; Crespo, J.; Fukase, K.; Inamura, S.; Kusumoto, S.; Hashimoto, M.; et al. Host recognitionof bacterial muramyl dipeptide mediated through NOD2. Implications for Crohn's disease. J. Biol. Chem. 2003, 278, 5509-5512. [CrossRef]

35. Girardin, S.E.; Boneca, I.G.; Viala, J.; Chamaillard, M.; Labigne, A.; Thomas, G.; Philpott, D.; Sansonetti, P.J. Nod2 is a general sensor of peptidoglycan through muramyl dipeptide (MDP) detection. J. Biol. Chem. 2003, 278, 8869-8872. [CrossRef] [PubMed] 
36. Ogura, Y.; Bonen, D.K.; Inohara, N.; Nicolae, D.L.; Chen, F.F.; Ramos, R.; Britton, H.; Moran, T.; Karaliuskas, R.; Duerr, R.H.; et al. A frameshift mutation in NOD2 associated with susceptibility to Crohn's disease. Nature 2001, 411, 603-606. [CrossRef]

37. Iwanaga, Y.; Davey, M.P.; Martin, T.M.; Planck, S.R.; DePriest, M.L.; Baugh, M.M.; Suing, C.M.; Rosenbaum, J.T. Cloning, sequencing and expression analysis of the mouse NOD2/CARD15 gene. Inflamm. Res. 2003, 52, 272-276. [CrossRef]

38. Strober, W.; Murray, P.J.; Kitani, A.; Watanabe, T. Signalling pathways and molecular interactions of NOD1 and NOD2. Nat. Rev. Immunol. 2006, 6, 9-20. [CrossRef] [PubMed]

39. Park, J.H.; Kim, Y.G.; McDonald, C.; Kanneganti, T.D.; Hasegawa, M.; Body-Malapel, M.; Inohara, N.; Nunez, G. RICK/RIP2 mediates innate immune responses induced through Nod1 and Nod2 but not TLRs. J. Immunol. 2007, 178, 2380-2386. [CrossRef] [PubMed]

40. Ogura, Y.; Inohara, N.; Benito, A.; Chen, F.F.; Yamaoka, S.; Núñez, G. Nod2, a Nod1/Apaf-1 family member that is restricted to monocytes and activates NF-кB. J. Biol. Chem. 2001, 276, 4812-4818. [CrossRef]

41. Zou, P.F.; Chang, M.X.; Li, Y.; Xue, N.N.; Li, J.H.; Chen, S.N.; Nie, P. NOD2 in zebrafish functions in antibacterial and also antiviral responses via NF-кB, and also MDA5, RIG-I and MAVS. Fish Shellfish Immunol. 2016, 55, 173-185. [CrossRef]

42. Swain, B.; Basu, M.; Samanta, M. NOD1 and NOD2 receptors in mrigal (Cirrhinus mrigala): Inductive expression and downstream signalling in ligand stimulation and bacterial infections. J. Biosci. 2013, 38, 533-548. [CrossRef] [PubMed]

43. Berzofsky, J.A.; Brett, S.J.; Streicher, H.Z.; Takahashi, H. Antigen processing for presentation to T lymphocytes: Function, mechanisms, and implications for the T-cell repertoire. Immunol. Rev. 1988, 106, 5-31. [CrossRef] [PubMed]

44. Vyas, J.M.; Van der Veen, A.G.; Ploegh, H.L. The known unknowns of antigen processing and presentation. Nat. Rev. Immunol. 2008, 8, 607-618. [CrossRef] [PubMed]

45. Yamaguchi, Y.; Iseoka, H.; Kobayashi, A.; Maeda, M. The carboxyl terminal sequence of rat transporter associated with antigen processing (TAP)-like (ABCB9) is heterogeneous due to splicing of its mRNA. Biol. Pharm. Bull. 2004, 27, 100-104. [CrossRef] [PubMed]

46. Abele, R.; Tampé, R. The ABCs of immunology: Structure and function of TAP, the transporter associated with antigen processing. Physiology 2004, 19, 216-224. [CrossRef] [PubMed]

47. Dick, T.P.; Ruppert, T.; Groettrup, M. Coordinated dual cleavages induced by the proteasome regulator PA28 lead to dominant Mhc ligands. Cell 1996, 86, 253-262. [CrossRef]

48. Kim, D.H.; Lee, S.M.; Hong, B.Y.; Kim, Y.T.; Choi, T.J. Cloning and sequence analysis of cDNA for the proteasome activator PA28- $\beta$ subunit of flounder (Paralichthys olivaceus). Mol. Immunol. 2003, 40, 611-616. [CrossRef]

49. Zhang, J.M.; An, J. Cytokines, inflammation and pain. Int. Anesthesiol. Clin. 2007, 45, 27. [CrossRef]

50. Opal, S.M.; Vera, A.D. Anti-inflammatory cytokines. Chest 2000, 117, 1162-1172. [CrossRef]

51. Fenner, J.E.; Starr, R.; Cornish, A.L.; Zhang, J.G.; Metcalf, D.; Schreiber, R.D.; Sheehan, K.; Hilton, D.J.; Alexander, W.S.; Hertzog, P.J. Suppressor of cytokine signaling 1 regulates the immune response to infection by a unique inhibition of type I interferon activity. Nat. Immunol. 2006, 7, 33-39. [CrossRef]

52. Gómez-Abellán, V.; Sepulcre, M.P. The role of prostaglandins in the regulation of fish immunity. Mol. Immunol. 2016, 69, 139-145. [CrossRef] [PubMed]

53. Cai, B.; Wu, J.; Yu, X.; Su, X.Z.; Wang, R.F. FOSL1 inhibits type I interferon responses to malaria and viral infections by blocking TBK1 and TRAF3/TRIF interactions. MBio 2017, 8, e02161-16. [CrossRef]

54. Li, L.; Shu, M.Q.; Chen, J. CYLD deficiency exacerbates lipopolysaccharide (LPS)-induced pyroptosis in astrocytes of mice with sepsis. Biochem. Biophys. Res. Commun. 2019, 514, 1066-1073. [CrossRef] [PubMed]

55. Clarke, C.J.; Hales, A.; Hunt, A.; Foxwell, B.M. IL-10-mediated suppression of TNF- $\alpha$ production is independent of its ability to inhibit NF-kB activity. Eur. J. Immunol. 1998, 28, 1719-1726. [CrossRef]

56. Gerard, C.; Bruyns, C.; Marchant, A.; Abramowicz, D.; Vandenabeele, P.; Delvaux, A.; Fiers, W.; Goldman, M.; Velu, T. Interleukin 10 reduces the release of tumor necrosis factor and prevents lethality in experimental endotoxemia. J. Exp. Med. 1993, 177, 547-550. [CrossRef]

57. Marchant, A.; Bruyns, C.; Vandenabeele, P.; Ducarme, M.; Gérard, C.; Delvaux, A.; De Groote, D.; Abramowicz, D.; Velu, T.; Goldman, M. Interleukin-10 controls interferon- $\gamma$ and tumor necrosis factor production during experimental endotoxemia. Eur. J. Immunol. 1994, 24, 1167-1171. [CrossRef] [PubMed] 
58. Opal, S.M.; Wherry, J.C.; Grint, P. Interleukin-10: Potential benefits and possible risks in clinical infectious diseases. Clin. Infect. Dis. 1998, 27, 1497-1507. [CrossRef]

59. Piazzon, M.C.; Savelkoul, H.F.; Pietretti, D.; Wiegertjes, G.F.; Forlenza, M. Carp IL10 has anti-inflammatory activities on phagocytes, promotes proliferation of memory $\mathrm{T}$ cells, and regulates $\mathrm{B}$ cell differentiation and antibody secretion. J. Immunol. 2015, 194, 187-199. [CrossRef]

60. Nam, B.H.; Moon, J.Y.; Park, E.H.; Kim, Y.O.; Kim, D.G.; Kong, H.J.; Kim, W.; Jung, H.; Jee, Y.J.; Lee, S.; et al. Conserved gene structure and function of interleukin-10 in teleost fish. J. Anim. Vet. Adv. 2014, 13, 774-782.

61. Matsumoto, M.; Amer, M.T.; Araki, K.; Nishitani, A.; Hayashi, K.; Takeuchi, Y.; Shiozaki, K.; Yamamoto, A. Amberjack Seriola dumerili interleukin-10 negatively suppresses host cell-mediated immunity. Fish. Sci. 2018, 84, 857-867. [CrossRef]

62. Huo, H.J.; Chen, S.N.; Li, L.; Nie, P. Functional characterization of IL-10 and its receptor subunits in a perciform fish, the mandarin fish, Siniperca chuatsi. Dev. Comp. Immunol. 2019, 97, 64-75. [CrossRef] [PubMed]

63. Seppola, M.; Larsen, A.N.; Steiro, K.; Robertsen, B.; Jensen, I. Characterisation and expression analysis of the interleukin genes, IL-1ß, IL-8 and IL-10, in Atlantic cod (Gadus morhua L.). Mol. Immunol. 2008, 45, 887-897. [CrossRef] [PubMed]

64. Fujimoto, M.; Naka, T. SOCS1, a negative regulator of cytokine signals and TLR responses, in human liver diseases. Gastroent. Res. Pract. 2010, 2010, 470468. [CrossRef] [PubMed]

65. Mansell, A.; Smith, R.; Doyle, S.L.; Gray, P.; Fenner, J.E.; Crack, P.J.; Nicholson, S.E.; Hilton, D.J.; O’Neill, L.A.J.; Hertzog, P.J. Suppressor of cytokine signaling 1 negatively regulates Toll-like receptor signaling by mediating Mal degradation. Nat. Immunol. 2006, 7, 148-155. [CrossRef] [PubMed]

66. Zhao, X.; Huo, R.; Song, W.; Xu, T. Characterization and role of suppressor of cytokine signaling 1a (SOCS1a) in a teleost fish, Miichthys miiuy. Dev. Comp. Immunol. 2018, 78, 124-131. [CrossRef] [PubMed]

67. Skjesol, A.; Liebe, T.; Iliev, D.B.; Thomassen, E.I.; Tollersrud, L.G.; Sobhkhez, M.; Joensen, L.L.; Secombes, C.J.; Jørgensen, J.B. Functional conservation of suppressors of cytokine signaling proteins between teleosts and mammals: Atlantic salmon SOCS1 binds to JAK/STAT family members and suppresses type I and II IFN signaling. Dev. Comp. Immunol. 2014, 45, 177-189. [CrossRef]

68. Montero, J.; Gómez-Abellán, V.; Arizcun, M.; Mulero, V.; Sepulcre, M.P. Prostaglandin E2 promotes M2 polarization of macrophages via a cAMP/CREB signaling pathway and deactivates granulocytes in teleost fish. Fish Shellfish Immunol. 2016, 55, 632-641. [CrossRef]

69. Medeiros, A.; Peres-Buzalaf, C.; Fortino Verdan, F.; Serezani, C.H. Prostaglandin E2 and the Suppression of Phagocyte Innate Immune Responses in Different Organs. Mediat. Inflamm. 2012, 2012, 327568. [CrossRef]

70. Norgaard, P.; Hougaard, S.; Poulsen, H.S.; Spang-Thomsen, M. Transforming growth factor $\beta$ and cancer. Cancer Treat. Rev. 1995, 21, 367-403. [CrossRef]

71. Roberts, A.B.; Sporn, M.B. Physiological actions and clinical applications of transforming growth factor- $\beta$ (TGF- $\beta$ ). Growth Factors 1993, 8, 1-9. [CrossRef]

72. Hanada, T.; Yoshimura, A. Regulation of cytokine signaling and inflammation. Cytokine Growth Factor Rev. 2002, 13, 413-421. [CrossRef]

73. Massoumi, R.; Paus, R. Cylindromatosis and the CYLD gene: New lessons on the molecular principles of epithelial growth control. Bioessays 2007, 29, 1203-1214. [CrossRef] [PubMed]

74. Kovalenko, A.; Chable-Bessia, C.; Cantarella, G.; Israël, A.; Wallach, D.; Courtois, G. The tumour suppressor CYLD negatively regulates NF-kB signalling by deubiquitination. Nature 2003, 424, 801-805. [CrossRef]

75. Reiley, W.W.; Zhang, M.; Jin, W.; Losiewicz, M.; Donohue, K.B.; Norbury, C.C.; Sun, S.C. Regulation of T cell development by the deubiquitinating enzyme CYLD. Nat. Immunol. 2006, 7, 411-417. [CrossRef] [PubMed]

76. Massoumi, R.; Chmielarska, K.; Hennecke, K.; Pfeifer, A.; Fässler, R. Cyld inhibits tumor cell proliferation by blocking Bcl-3-dependent NF-kB signaling. Cell 2006, 125, 665-677. [CrossRef]

77. Belmonte, R.; Wang, T.; Duncan, G.J.; Skaar, I.; Mélida, H.; Bulone, V.; Van West, P.; Secombes, C.J. Role of pathogen-derived cell wall carbohydrates and prostaglandin E2 in immune response and suppression of fish immunity by the oomycete Saprolegnia parasitica. Infect. Immun. 2014, 82, 4518-4529. [CrossRef] [PubMed]

78. Alba-Loureiro, T.C.; Martins, E.F.; Miyasaka, C.K.; Lopes, L.R.; Landgraf, R.G.; Jancar, S.; Curi, R.; Sannomiya, P. Evidence that arachidonic acid derived from neutrophils and prostaglandin E2 are associated with the induction of acute lung inflammation by lipopolysaccharide of Escherichia coli. Inflamm. Res. 2004, 53, 658-663. [CrossRef] [PubMed] 
79. He, L.K.; Liu, L.H.; Hahn, E.; Gamelli, R.L. The expression of cyclooxygenase and the production of prostaglandin E2 in neutrophils after burn injury and infection. J. Burn Care Rehabil. 2001, 22, 58-64. [CrossRef]

80. Hecker, G.; Ney, P.; Schrör, K. Cytotoxic enzyme release and oxygen centered radical formation in human neutrophils are selectively inhibited by E-type prostaglandins but not by PGI2. NS Arch. Pharmacol. 1990, 341, 308-315. [CrossRef]

81. Gryglewski, R.J.; Szczeklik, A.; Wandzilak, M. The effect of six prostaglandins, prostacyclin and iloprost on generation of superoxide anions by human polymorphonuclear leukocytes stimulated by zymosan or formyl-methionyl-leucyl-phenylalanine. Biochem. Pharmacol. 1987, 36, 4209-4213. [CrossRef]

82. Sedgwick, J.B.; Berube, M.L.; Zurier, R.B. Stimulus-dependent inhibition of superoxide generation by prostaglandins. Clin. Immunol. Immunopathol. 1985, 34, 205-215. [CrossRef]

83. Wise, H. The inhibitory effect of prostaglandin E2 on rat neutrophil aggregation. J. Leukoc. Biol. 1996, 60, 480-486. [CrossRef] [PubMed]

84. Secombes, C.J.; Wang, T.; Hong, S.; Peddie, S.; Crampe, M.; Laing, K.J.; Cunningham, C.; Zou, J. Cytokines and innate immunity of fish. Dev. Comp. Immunol. 2001, 25, 713-723. [CrossRef]

85. Fast, M.D.; Ross, N.W.; Johnson, S.C. Prostaglandin E2 modulation of gene expression in an Atlantic salmon (Salmo salar) macrophage-like cell line (SHK-1). Dev. Comp. Immunol. 2005, 29, 951-963. [CrossRef] [PubMed]

86. Haddad, G.; Hanington, P.C.; Wilson, E.C.; Grayfer, L.; Belosevic, M. Molecular and functional characterization of goldfish (Carassius auratus L.) transforming growth factor beta. Dev. Comp. Immunol. 2008, 32, 654-663. [CrossRef] [PubMed]

87. Yang, M.; Zhou, H. Grass carp transforming growth factor-beta 1 (TGF-beta 1): Molecular cloning, tissue distribution and immunobiological activity in teleost peripheral blood lymphocytes. Mol. Immunol. 2008, 45, 1792-1798. [CrossRef] [PubMed]

88. Stegmann, C.M.; Lührmann, R.; Wahl, M.C. The crystal structure of PPIL1 bound to cyclosporine A suggests a binding mode for a linear epitope of the SKIP protein. PLoS ONE 2010, 5, e10013. [CrossRef]

89. Rzymski, T. The PHD Finger Protein 5 is a Part of the Spliceosome and Acts as a DNA-Binding Protein. Ph.D. Thesis, University of Göttingen, Göttingen, Germany, 2004.

90. Guan, X.L.; Zhang, B.C.; Sun, L. pol-miR-194a of Japanese flounder (Paralichthys olivaceus) suppresses type I interferon response and facilitates Edwardsiella tarda infection. Fish Shellfish Immunol. 2019, 87, 220-225. [CrossRef]

91. Li, X.P.; Sun, L. TLR7 is required for optimal immune defense against bacterial infection in tongue sole (Cynoglossus semilaevis). Fish Shellfish Immunol. 2015, 47, 93-99. [CrossRef]

92. Li, M.F.; Sun, L. Characterization of a teleost membrane-associated protein that is involved in the regulation of complement activation and bacterial infection. Dev. Comp. Immunol. 2018, 79, 142-149. [CrossRef]

93. Sui, Z.H.; Xu, H.; Wang, H.; Jiang, S.; Chi, H.; Sun, L. Intracellular trafficking pathways of Edwardsiella tarda: From clathrin-and caveolin-mediated endocytosis to endosome and lysosome. Front. Cell. Infect. Microbiol. 2017, 7, 400. [CrossRef] [PubMed]

94. Wang, S.; Zhang, J.; Jiao, W.; Li, J.; Xun, X.; Sun, Y.; Hu, X. Scallop genome provides insights into evolution of bilaterian karyotype and development. Nat. Ecol. Evol. 2017, 1, 1-12. [CrossRef] [PubMed]

95. Langmead, B.; Salzberg, S.L. Fast gapped-read alignment with Bowtie 2. Nat. Methods 2012, 9, 357-359. [CrossRef]

96. Kim, D.; Pertea, G.; Trapnell, C.; Pimentel, H.; Kelley, R.; Salzberg, S.L. TopHat2: Accurate alignment of transcriptomes in the presence of insertions, deletions and gene fusions. Genome Biol. 2013, 14, R36. [CrossRef] [PubMed]

97. Trapnell, C.; Roberts, A.; Goff, L.; Pertea, G.; Kim, D.; Kelley, D.R.; Pimentel, H.; Salzberg, S.L.; Rinn, J.L.; Pachter, L. Differential gene and transcript expression analysis of RNA-seq experiments with TopHat and Cufflinks. Nat. Protoc. 2012, 7, 562-578. [CrossRef] [PubMed]

98. Li, B.; Dewey, C.N. RSEM: Accurate transcript quantification from RNA-Seq data with or without a reference genome. BMC Bioinform. 2011, 12, 323. [CrossRef] [PubMed]

99. Trapnell, C.; Williams, B.A.; Pertea, G.; Mortazavi, A.; Kwan, G.; van Baren, M.J.; Salzberg, S.L.; Wold, B.J.; Pachter, L. Transcript assembly and quantification by RNA-Seq reveals unannotated transcripts and isoform switching during cell differentiation. Nat. Biotechnol. 2010, 28, 511-515. [CrossRef] 
100. Robinson, M.D.; Smyth, G.K. Small-sample estimation of negative binomial dispersion, with applications to SAGE data. Biostatistics 2008, 9, 321-332. [CrossRef]

101. Ning, X.H.; Sun, L. Gene network analysis reveals a core set of genes involved in the immune response of Japanese flounder (Paralichthys olivaceus) against Vibrio anguillarum infection. Fish Shellfish Immunol. 2020, 98, 800-809. [CrossRef]

102. Li, Z.; Liu, X.; Liu, J.; Zhang, K.; Yu, H.; He, Y.; Wang, X.; Qi, J.; Wang, Z.; Zhang, Q. Transcriptome profiling based on protein-protein interaction networks provides a core set of genes for understanding blood immune response mechanisms against Edwardsiella tarda infection in Japanese flounder (Paralichthys olivaceus). Dev. Comp. Immunol. 2018, 78, 100-113. [CrossRef]

(C) 2020 by the authors. Licensee MDPI, Basel, Switzerland. This article is an open access article distributed under the terms and conditions of the Creative Commons Attribution (CC BY) license (http://creativecommons.org/licenses/by/4.0/). 